\title{
Differences in the "Inclusion Need Orientation" of Students From a Historically Black University Versus Predominately White Institutions
}

\author{
Kathleen Gurley and Ann Herd
}

The importance of inclusion and social adjustment within the college or university setting have been well documented by studies on student retention. The primary purpose of this study was to investigate the difference in "inclusion need orientation" between students at three different universities - a historically Black university (HBCU) and two predominantly White institutions (PWI). Students at the HBCU had significantly lower scores than the students at the PWIs on "expressed and wanted inclusion" using Schutz's FIRO-B (Fundamental Interpersonal Relations Orientation) instrument. Lower scores on expressed inclusion need suggest that students at the HBCU feel less comfortable asking others to join them in activities than students at the PWIs, while lower scores on wanted inclusion need suggest that students at the HBCU have less desire to be invited to join activities than students at the PWIs. Implications of these findings are discussed.

A recent article in the Baltimore Sun (Kiehl, 2009) pointed out the growing gap between graduation rates at historically Black colleges and universities (HBCUs) and the rest of the state universities in Maryland. The gap between Black students and other students has widened over the last three years, from $15 \%$ to $25 \%$. Some of the predominantly White institutions (PWI) in the system have closed this gap to near zero. These statistics raise the question on why HBCUs struggle to increase their graduation rate. This study seeks to help understand the difference between the HBCUs and PWIs on the dimension of social integration and inclusion behaviors of students.

One of the keys to academic success for college students is feeling connected to their institutions by being actively involved in both academic and out-of-class activities (Bagayoko \& Kelley, 1994; Datnow \& Cooper, 1997). HBCUs are designed to provide supportive social environments, particularly for African American college students, which encourage students to pursue academic and out-of-class activities and to develop positive self images and strong racial identities (Berger \& Milem, 2000; Cole \& Omari, 2003; Credle \& Dean, 1991; Tatum, 2004).

Kathleen Gurley (kgurley@uncfsu.edu) is an Assistant Professor in Management in the School of Business \& Economics at Fayetteville State University.

Ann Herd (aherd@umuc.edu) is a Professor in the Graduate School of Management and Technology at University of Maryland University College. 
Because HBCUs are designed to provide supportive social environments, it would be expected that students would be comfortable expressing inclusive behaviors. Although there has been considerable literature published on the comparison of HBCUs and PWIs, no research has been done using the Fundamental Interpersonal Relations Orientation (FIRO) theory developed by Schutz to identify differences in inclusion behaviors among college students at these institutions. Research by Schutz (1994) suggests that an individual's interpersonal inclusion need orientation influences his or her engagement in positive inclusion behaviors, such as making friends and joining organizations, which help the college student become adjusted to the college environment.

The FIRO-B instrument adds value to previous studies that researched social support as a factor which improves retention. Social support has been operationalized as a measure of a student's perception of the support students receive from family and friends (Procidano \& Heller, 1983). The FIRO-B, instead, looks at the self-reported behavioral pattern of the student and suggests how those behaviors contribute to the student's interpersonal relationships. The feedback students receive allow them to make choices about modifying their behavior if they are not satisfied with the current social situation. The FIRO-B instrument is more than a research variable; it is a means of improving interpersonal relationships and helping students to become integrated in the social environment of the university.

\section{Literature Review}

\section{Inclusion and Academic Success}

The importance of inclusion and social adjustment within college or university settings has been well documented by studies investigating factors related to college student retention and success in college (e.g., Bagayoko \& Kelley, 1994; Cabrera, Castaneda, Nora, \& Hengstler, 1992; Drew, 1990; Grant-Vallone, Reid, Umali, \& Pohlert, 2004; Tinto, 1993). Tinto's (1993) early model, based on a theory of person-environment fit, looked at factors that increased academic persistence, a student's desire to remain in college and graduate. He found that students who develop satisfying relationships with peers tend to earn better grades and are more inclined to remain in college than are students who fail to develop these relationships. A similar study by Napoli and Wortman (1998) found that students who have a high level of social support from their peers and family members indicate higher levels of social and academic adjustment and earn higher first-year grade point averages than students reporting lower levels of social support.

A more recent study of disadvantaged college students by Grant-Vallone et al. (2004) found that those students who reported greater levels of peer and social support had better academic and social adjustment and were more committed to achieving college degree. A study of 527 first-year female undergraduates (Rayle, Robinson Kurpius, \& Arredondo, 2006) showed that social support was the 
strongest predictor of academic persistence among the three constructs studied, the other two being self-belief and university comfort. Nicpon, Huser, Blanks, Sollenberger, Befort, and Robinson Kurpius (2006) provide an excellent review of the past research on social integration using Tinto's model. They reported that loneliness negatively correlates with social support and academic persistence. In addition, inclusion and involvement in both academic and out-of-class activities has been shown to lead to a wide range of positive student outcomes such as cognitive and intellectual skills development, ethical development, psychosocial development, and positive self-image (Datnow \& Cooper, 1997; Harper, Carini, Bridges, \& Hayek, 2004).

Most of the early studies on retention, including Tinto's model (1993), were carried out at PWIs. Studies conducted at HBCUs have shown less support for Tinto's model (Washington, 1996; Watkins, 1996). Other studies have focused on African American students. Gloria, Robinson Kurpius, Hamilton, and Wilson (1999) conducted a study with 98 African American undergraduate students attending a predominantly White university. They investigated the influence of social support, university comfort, and self belief on persistence decisions and found that university comfort and social support were the strongest predictors of the African American students' decisions to stay in college. The university comfort variable in this study included measures of college stress, cultural fit, and how welcoming the university environment was perceived. Pascarella (1985) found that campus involvement had a stronger positive effect on graduation rate for Black male students than on White students. Campus involvement was also found to be more significant than academic integration in predicting degree completion for Black males. Social support was also found to be a factor in the level of stress experienced by African American students; the stress level varied based on the school's racial composition (Negga, Applewhite, \& Livingston, 2007).

Research has shown that HBCUs provide a supportive social environment conducive to personal and academic development as evidenced by the number of students who reported being satisfied in their adjustment and achievement (Harper et al., 2004; Tobolowsky, Outcalt, \& McDonough, 2005). Specific studies have found that HBCUs provide a positive campus climate and wide array of culturally appealing activities for African American students (Allen, 1992; Berger \& Milem, 2000; Davis, 1991). Fleming's (1984) analysis confirmed that these efforts lead to students feeling a greater sense of connectedness, power, and affiliation at HBCUs than at PWIs.

\section{Interpersonal Need Orientation}

The Fundamental Interpersonal Relations Orientation-Behavior (FIRO) theory developed by Schutz $(1958,1966)$ examines interpersonal behavior built around the concept of interpersonal needs and is operationalized in the FIRO-B questionnaire. Schutz's theory is based on the assumption that interpersonal needs motivate behavior and that each person has a unique set of psychic needs. These needs lead to a pattern of interpersonal behaviors and expectations. These needs 
change over time and with experience, and people can choose to modify their patterns of behavior to increase their satisfaction with their interpersonal relationships. Inclusion is one of the interpersonal needs and refers to the need for belonging and interaction with others.

The need for inclusion is comprised of two scales: expressed and wanted behavior. Expressed behavior indicates how the respondent acts toward others; wanted behavior indicates what the respondent desires from others in relation to the need for inclusion.

Schutz (1994) further characterizes the extremes of inclusion needs by describing them as under-social or over-social behaviors:

When my relations are under-social ... I am introverted and withdrawn. I want to maintain distance between myself and others. I do not want to become enmeshed with people and thereby lose my privacy. My greatest fear is that people will ignore or abandon me. My deepest anxiety is that I am worthless, insignificant, and unimportant. (p. 29)

In contrast, when my relations are over-social . . I am extroverted. I seek people incessantly, and I want them to seek me out. I would enjoy going every night to a bar where everybody knows my name. My fear is that people will ignore me. My unconscious attitude is "Although no one is interested in me, I will force them to pay attention to me in any way I can." (p. 29)

The FIRO-B questionnaire has had widespread use and popularity. Hurley (1990) estimated that FIRO-B received about 25 citations annually in the Social Science Citation Index, and Furnham $(1990,1996)$ described it as one of the three most widely used questionnaires in Occupational Psychology. Schutz (1977) validated the instrument with more than 6,000 people from the public school community. Results from reliability and validity studies of the instrument were published by Schutz in the FIRO Awareness Scales Manual (1978), with reported reliabilities on all the subscales over .80 indicating high reliability. The FIRO-B instrument has been used to study interpersonal needs affecting group dynamics in work settings (Fisher, Macrosson, \& Semple, 2001; Hawley \& Heinen, 1979; Herzberg, 1985; Siegel \& O'Shaughnessy, 2008; Siegel, Smith, \& Mosca, 2001; Johnson, Winter, Reio, Thompson, \& Petrosko, 2008), psychotherapeutic settings (cf. Gassner, 1970; Sapolsky, 1965), as well as educational settings (Abrams \& Abrams, 1974; Schutz, 1977).

\section{Overview of the Present Study}

Because previous research suggested the importance of social support for college students' retention and adjustment, and because research comparing HBCUs and PWIs has suggested that HBCUs in particular place great emphasis on developing and encouraging students' inclusive behaviors and orientation, the present study was conducted to investigate differences in inclusion need 
orientation among college business students at an HBCU versus those at two comparably-sized PWIs. It was expected that students at the HBCU would display greater inclusion behavior and orientation than the students at the PWI because the HBCU in this study placed a great deal of emphasis on creating a nurturing environment with plenty of opportunities for inclusion activities for students. The following hypothesis was explored in the present study:

Hypothesis: There will be a significant difference in inclusion need orientation between HBCU and PWI students, with the HBCU students scoring higher on expressed and wanted inclusion need orientation than the PWI students.

\section{Method}

\section{Overview}

A survey/questionnaire method was decided upon for this study. Since the FIRO-B is a questionnaire instrument, the study questionnaire instrument could be given to students as a natural follow-up to their taking the FIRO-B, facilitating quick and unobtrusive collection of data for the study. The institutions from which the sample of student participants was solicited were carefully chosen to be comparable in overall size and racial diversity, with the HBCU's student body consisting mainly of African American students and the PWIs' student bodies consisting mainly of Caucasian students. Students chosen to participate were enrolled in the same course in all three universities. This course also occurred within the same time frame (junior year) in the students' curricula at all three universities. Business students were sought for this study because previous research has suggested that inclusion needs are particularly important for business students when they get their first jobs out of college (Siegel, Smith, \& Mosca, 2001; Siegel \& O'Shaughnessy, 2008). In addition, the FIRO-B instrument could be incorporated into a meaningful learning experience for the business students in the class after the data for the study were collected.

\section{Participants}

Participants in the study consisted of 179 business students from three small universities in the southeastern United States. The HBCU is a state university, and the two PWIs are private, religious universities. All three schools have student enrollments of approximately 6,000 and an average class size of 22-25 students. The diversity of the student population at the three universities and of the samples is indicated in Table 1. 
TABLE 1

\section{Diversity of Student Populations and Study Sample}

\begin{tabular}{lcccc} 
University (2005 Data) & Caucasian & $\begin{array}{c}\text { African } \\
\text { American }\end{array}$ & Hispanic & Other \\
\hline HBCU student population & $17.0 \%$ & $75.0 \%$ & $4.0 \%$ & $4.0 \%$ \\
HBCU study sample & 15.0 & 75.0 & 3.0 & 7.0 \\
First PWI student population & 78.0 & 9.0 & 3.0 & 10.0 \\
First PWI study sample & 83.2 & 5.6 & 5.6 & 5.6 \\
Second PWI student population & 64.0 & 19.4 & 6.6 & 10.0 \\
Second PWI study sample & 76.0 & 24.0 & 0.0 & 0.0
\end{tabular}

One hundred seventeen (65\%) of the students were from an HBCU, while 62 (35\%) of the students were from PWIs.

\section{Procedure}

The FIRO-B instrument was administered to undergraduate students at all three universities as part of a discussion on human motivation in their Principles of Management course. The self-scorable version of the questionnaire gave the students immediate feedback, facilitating the discussion of Schutz's theory on interpersonal behavior. Students willing to share their results for research purposes (over 90\%) filled out and returned a demographic sheet along with their FIRO-B survey. The students' scoring of the FIRO-B results was checked for accuracy prior to entering the results into a database.

The data from the two PWIs were compared first to determine if there was a statistical difference in the inclusion orientation scores. The comparison of the means for expressed and wanted inclusion for the two PWIs with the two-tailed $t$ test are shown in Table 2.

TABLE 2

\section{Comparison of Mean Inclusion Need Scores for Two PWI}

\begin{tabular}{llrrrrrr} 
FIRO-B Scale & University & $\boldsymbol{N}$ & $\boldsymbol{M}$ & $\boldsymbol{S D}$ & $\boldsymbol{S E}$ & $\boldsymbol{t}$ & $\boldsymbol{p}$ \\
\hline Expressed Inclusion & PWI - 1 & 36 & 4.61 & 2.59 & .431 & -0.126 & 0.90 \\
& PWI - 2 & 26 & 4.69 & 2.38 & .467 & & \\
\multirow{3}{*}{ Wanted Inclusion } & PWI - 1 & 36 & 4.64 & 3.63 & .604 & 0.330 & 0.74 \\
& PWI - 2 & 26 & 4.35 & 3.19 & .625 & &
\end{tabular}


No statistical difference was found in the inclusion scores between the two PWIs; therefore, the data from the two schools were combined.

\section{Results}

The comparison of the means of students at the HBCU and the PWI students' inclusion scores using a two-tailed $t$ test is shown in Table 3.

TABLE 3

Mean Inclusion Need Scores of HBCU and PWI Students

\begin{tabular}{llrrrrrr} 
FIRO-B Scale & University & $\boldsymbol{N}$ & $\boldsymbol{M}$ & $\boldsymbol{S D}$ & $\boldsymbol{S E}$ & $\boldsymbol{t}$ & $\boldsymbol{p}$ \\
\hline Expressed Inclusion & HBCU & 117 & 3.23 & 1.99 & .184 & $4.15 .000^{* *}$ \\
& PWIs & 62 & 4.64 & 2.48 & .315 & & \\
\multirow{2}{*}{ Wanted Inclusion } & HBCU & 117 & 2.88 & 3.25 & .301 & $3.09 .002^{* *}$ \\
& PWIs & 62 & 4.52 & 3.42 & .435 & \\
$* p<.05, * * p<.01$ & & & & & & & \\
& & & & & &
\end{tabular}

Table 3 indicates that HBCU students' scores were significantly lower than PWI students' scores on both expressed and wanted inclusion scales. Thus, Hypothesis 1 is partially supported, but in the opposite direction expected.

\section{Discussion}

The results of the present study suggest that HBCU business students have lower inclusion needs than PWI business students. These results, along with study limitations and implications for future research, are discussed below.

HBCU students reported lower expressed and wanted inclusion needs than PWI students. For expressed inclusion, these results suggest that HBCU students express the need to include others in group interactions less frequently than students at a PWI and may be less vocal in getting other students involved on team projects. The results for wanted inclusion needs suggest that HBCU students may have lesser desires to be included by fellow students in group interactions, class discussions, and team projects than PWI students.

These results showing lower inclusion needs for HBCU students were in the opposite direction than expected. A more in-depth comparison of the three universities might help to explain the results. All three universities talk of providing a nurturing environment where students come first, and class sizes are small to encourage faculty and student interaction. One main difference between 
the universities is the average SAT score. The average SAT score for the HBCU was 847 versus the first PWI at 1085 and the second PWI at 999.

A possible explanation for the lower inclusion need orientation for HBCU students may be that students who are more "at risk" because of lower SAT scores may be less comfortable in the college environment and, therefore, less willing to show inclusive behaviors. HBCUs traditionally have a higher percent of firstgeneration college students. The self-identity of these students may be less aligned with academic success. Although research has shown that African American students who attend HBCUs rather than PWIs have higher self-ratings in academic self-efficacy and psychosocial wellness (Berger \& Milem, 2000), the results from the present study suggest that HBCU students still may not feel as comfortable in college surroundings as students at predominately White institutions.

Schutz's theory of fundamental interpersonal relations orientation views the need orientation as developmental in that an individual's scores are expected to change as the person deals with and resolves inclusion issues. To help students make the social adjustment to college, many universities are now forming learning communities for "at risk" students to increase peer support and social integration into campus life (Andrade, 2007). The HBCU in this study has established such a program for "at risk" African American males. The program-a learning community-starts in the freshman year with a group of male students who study and go to class together. The students stay in their cohort group throughout their college years until graduation. This program is credited for improving retention rates from approximately $26 \%$ to $50 \%$ among students in the group.

Results from the present study showing that HBCU students have lower expressed and wanted inclusion needs than PWI students are somewhat disturbing given the research suggesting that expressed and wanted inclusion needs are important for students' social adjustment to college (Datnow \& Cooper, 1997; Harper et al., 2004) as well as success in gaining entry into and exhibiting successful performance in early business jobs after college (Johnson et al., 2008; Siegel et al., 2001). Future research is warranted to determine whether these results are replicated in other comparisons of HBCU and PWI students.

Results of the present study have implications for teaching and counseling practices. Strategies for reaching students with varying inclusion needs include diversifying the teaching techniques used in the classroom. For example, active learning techniques such as paired discussions, small group discussions, and group case studies may encourage inclusiveness at the small group level, practices with which students with low inclusive needs may be more comfortable. Explicitly stating inclusiveness norms in the classroom and restating the university's value on inclusiveness may also help reach students with varying needs.

Counselors involved in helping students make a successful transition to college may find the FIRO-B instrument useful as an assessment tool for providing feedback to students on their expressed and wanted inclusion needs and helping students set developmental goals related to their inclusion orientation (Thompson, 1998). Providing this feedback regarding inclusion orientation could help students recognize how their behaviors affect their relationships with others. Students who 
want to be included but are reluctant to ask others to join them in activities may be misunderstood by other students and be seen as aloof or unapproachable. The FIRO-B support materials provide developmental tips for such students and can be used as a part of ongoing counseling or coaching efforts.

\section{Future Directions}

A major limitation of this study was its sample size as it included only three universities. Studying more institutions across a larger geographical location would make the results more robust. Furthermore, as the sample used in the current study consisted of business students, future studies should investigate whether differences in inclusion needs are found among students with other majors. It seems likely that different majors may attract students with differing inclusion needs. Findings from studies comparing inclusion needs among different majors may be helpful for universities in their efforts to target special programs geared toward addressing inclusion need issues.

Future research should also ascertain which teaching styles best facilitate learning for students with differing inclusion needs. For example, small group discussion activities during class may prove to be a useful tool for encouraging greater inclusion behaviors among students, while group projects requiring intense participation outside of class may not be as well-received by students with low inclusion needs. Also of interest is using the FIRO-B instrument as a counseling or coaching tool for conducting counseling sessions with students who have low inclusion need scores. This instrument may prove to be an early warning device for students who are struggling with making the transition to college.

In summary, the present study provides evidence of differences in inclusion needs among business students in different university environments. Because such differences impact student learning and performance, future research is needed to ascertain the cause(s) of these differences and determine how to best facilitate learning and career preparation for students with differing inclusion needs.

\section{References}

Abrams, H., \& Abrams, L. (1974). Awareness of humanistic relationships between high school students at the 9th and 12th grade levels. Unpublished doctoral dissertation, School of Human Behavior, U.S. International University, San Diego, California.

Allen, W. R. (1992). The color of success: African American college student outcomes at predominantly White and historically Black colleges and universities. Harvard Educational Review, 62(1), 26-44.

Andrade, M. S. (2007-2008). Learning communities: Examining positive outcomes. Journal of College Student Retention, 9(1), 1-20.

Bagayoko, D., \& Kelley, E. L. (1994). The dynamics of student retention: A review and a prescription. Education, 115(1), 31-39. 
Berger, J. B., \& Milem J. F. (2000). Exploring the impact of historically Black colleges in promoting the development of undergraduates' self-concept. Journal of College Student Development, 41(4), 381-394.

Cabrera, A. F., Castaneda, M. B., Nora, A., \& Hengstler, D. (1992). The convergence between two theories of college persistence. Journal of Higher Education, 63(2), $144-163$.

Cole, E. R., \& Omari, S. R. (2003). Race, class and the dilemmas of upward mobility for African Americans. Journal of Social Issues, 59(4), 785-802.

Credle, J. O., \& Dean, G. J. (1991). A comprehensive model for enhancing Black student retention in higher education. Journal of Multicultural Counseling and Development, 19(4), 158-164.

Datnow, A., \& Cooper, R. (1997). Peer networks of African American students in independent schools: Affirming academic success and racial identity. The Journal of Negro Education, 66(1), 56-72.

Davis, R. B. (1991). Social support networks and undergraduate student academic-success-related outcomes: A comparison of Black students on Black and White campuses. In W. R. Allen, E. G., Epps, \& N. Z. Haniff (Eds.), College in Black and White: African American students in predominantly White and in historically Black universities (pp. 143-157). Albany, NY: State University of New York.

Drew, C. P. (1990). We can no longer love 'em and leave 'em: A paper on freshman retention. Community College Review, 17(4), 54-60.

Fisher, S. G., Macrosson, W. K., \& Semple, J. H. (2001). Control and Belbin's team roles. Personnel Review, 30(5/6), 578-589.

Fleming, J. (1984). Blacks in college: A comparative study of students' success in Black and White institutions. San Francisco: Jossey-Bass.

Furnham, A. (1990). The fakeability of the 16PF, Myers-Briggs and FIRO-B personality measures. Personality and Individual Differences, 11(7), 711-716.

Furnham, A. (1996). The FIRO-B, the learning style questionnaire, and the fivefactor model. Journal of Social Behavior and Personality, 11(2), 285-299.

Gassner, S. M. (1970). Relationship between patient-therapist compatibility and treatment effectiveness. Journal of Consulting and Clinical Psychology, 34(3), 408-414.

Gloria, A. M., Robinson Kurpius, S. E., Hamilton, K. D., \& Wilson, M. S. (1999). African American students' persistence at a predominantly White university: Influences of social support, university comfort, and self-beliefs. Journal of College Student Development, 40(3), 257-268.

Grant-Vallone, E., Reid, K., Umali, C., \& Pohlert, E. (2004). An analysis of the effects of self-esteem, social support, and participation in student support services on students' adjustment and commitment to college. Journal of College Student Retention, 5(3), 255-274.

Harper, S. R., Carini, R. M., Bridges, B. K., \& Hayek, J. C. (2004). Gender differences in student engagement among African American undergraduates at historically Black colleges and universities. Journal of College Student Development, 45(3), 271-284. 
Hawley, K. E., \& Heinen, J. S. (1979). Compatibility and task group performance. Human Relations, 32(7), 579-590.

Herzberg, E. (1985). Putting candidates to the test. Chief Executive, (Oct.), 17-20. Hurley, J. R. (1990). Does FIRO-B relate better to interpersonal or intrapersonal behavior? Journal of Clinical Psychology, 46(4), 454-460.

Johnson, A., Winter, P. A., Reio, T. G., Thompson, H. L., \& Petrosko, J. M. (2008). Managerial recruitment: The influence of personality and ideal candidate characteristics. The Journal of Management Development, 27, 631-637.

Kiehl, S. (2009). Black graduation gap grows at Maryland universities. Baltimore Sun, March 11, A3.

Napoli, A. R., \& Wortman, P. M. (1998). Psychosocial factors related to retention and early departure of two-year community college students. Research in Higher Education, 39(4), 419-455.

Negga, F., Applewhite, S., \& Livingston, I. (2007). African American college students and stress: School racial composition, self-esteem and social support. College Student Journal, 41(4), 823-831.

Nicpon, M. F., Huser, L., Blanks, E. H., Sollenberger, S., Befort, C., and Robinson Kurpius, S. E. (2006-2007). The relationship of loneliness and social support with college freshmen's academic performance and persistence. Journal of College Student Retention, 8(3), 345-358.

Pascarella, E. (1985). Racial differences in factors associated with bachelor's degree completion: A nine year follow-up. Research in Higher Education, 23, 351-373.

Procidano, M. E., \& Heller, K. (1983). Measures of perceived social support from friends and family: Three validation studies. American Journal of Community Psychology, 11(1), 1-23.

Rayle, A. D., Robinson Kurpius, S. E., \& Arredondo, P. (2006-2007). Relationship of self-beliefs, social support, and university comfort with the academic success of freshman college women. Journal of College Student Retention, 8(3), 325-343.

Sapolsky, A. (1965). A relationship between patient-doctor compatibility, mutual perception, and outcome of treatment. Journal of Abnormal Psychology, 70, $70-76$.

Schutz, W. C. (1958). FIRO: A three dimensional theory of interpersonal behavior. New York: Holt, Rinehart, \& Winston.

Schutz, W. C. (1966). The interpersonal underworld. Palo Alto, CA: Science and Behavior Books.

Schutz, W. C. (1977). Leaders of schools: FIRO theory applied to administrators. San Diego, CA: University Associates.

Schutz, W. C. (1978). FIRO awareness scales manual. Palo Alto, CA: Consulting Psychologists.

Schutz, W. C. (1994). The human element: Productivity, self-esteem, and the bottom line. San Francisco: Jossey-Bass.

Siegel, P. H., \& O'Shaughnessy, J. (2008). Social skill characteristics that promote successful careers in internal auditing. Internal Auditing, 23, 26-33.

Siegel, P. H., Smith, J. W., \& Mosca, J. B. (2001). Mentoring relationships and interpersonal orientation. Leadership and Organization Development Journal, 22(3), 114-126. 
Tatum, B. D. (2004). Family life and school experience: Factors in the racial identity development of Black youth in White communities. Journal of Social Issues, 60(1), 117-135.

Thompson, H. (1998). Using the FIRO-B and MBTI. Management and Organization Development, 21, 18-20.

Tinto, V. (1993). Leaving college: Rethinking the causes and cures of student attrition (2nd ed.). Chicago: University of Chicago Press.

Tobolowsky, B. F., Outcalt, C. L., \& McDonough, P. M. (2005). The role of HBCUs in the college choice process of African Americans in California. The Journal of Negro Education, 74(1) 63-75.

Washington, C. (1996). A study of early academic performance, attrition, and retention as related to selected cognitive, noncognitive and adjustment variables for African American college students attending a private, open admission historically Black institution. Dissertation, University of South Carolina, 225 pp., AAT 9711730

Watkins, J. F. (1996). A test of a psychosocial model of student attrition for African American students at a private, historically black college and university. Dissertation, Southern Illinois University at Carbondale, 121 pp., AAT 9708784 